\title{
Notes
}

\section{Outbreak of Powdery Mildew on Zinnia elegans by Golovinomyces cichoracearum in Korea, 2008-2010}

\author{
Mi-Jeong Park ${ }^{1}$, Ji-Hyun Park ${ }^{1}$, Hong Gi Kim² , Soon-Gu Lee, Young Jin Koh ${ }^{4}$, Byung Sup Kim ${ }^{5}$ Byeongjin Cha ${ }^{6}$, \\ Hyang Burm Lee ${ }^{7}$ and Hyeon-Dong Shin ${ }^{1 *}$ \\ ${ }^{1}$ Division of Environmental Science and Ecological Engineering, Korea University, Seoul 136-701, Korea \\ ${ }^{2}$ Department of Applied Biology, Chungnam National University, Daejeon 305-764, Korea \\ ${ }^{3}$ Department of Plant Medicine, Andong National University, Andong 760-749, Korea \\ ${ }^{4}$ Department of Plant Medicine, Sunchon National University, Suncheon 540-742, Korea \\ ${ }^{5}$ Department of Plant Science, Gangneung-Wonju National University, Gangneung 210-702, Korea \\ ${ }^{6}$ Department of Plant Medicine, Chungbuk National University, Cheongju 361-763, Korea \\ ${ }^{7}$ Division of Applied Bioscience and Biotechnology, Chonnam National University, Gwangju 500-757, Korea \\ (Received on December 30, 2010; Accepted on January 24, 2011)
}

\begin{abstract}
Podosphaera fusca (syn. Sphaerotheca fusca, S. fuliginea) is a causal agent of powdery mildew infections on Zinnia elegans, and has been documented in Korea since 1967. An outbreak involving about 1,000 plants in October 2008, in Yangpyeong, Korea, was caused by Golovinomyces cichoracearum. Further surveys of zinnia powdery mildew from 2008-2010 confirmed the widespread occurrence of Zinnia-Golovinomyces association in Korea. Chasmothecia of this fungus have not been found on $Z$. elegans in Korea. Analysis of internal transcribed spacer rDNA from five Korean collections confirmed the powdery mildew as $G$ cichoracearum. Comparison with the those from GenBank revealed $100 \%$ identity with sequences from zinnia powdery mildew, forming a monophyletic clade with $100 \%$ bootstrap support, and with those of $G$ cichoracearum parasitic on the hosts belonging to the tribe Heliantheae of the family Asteraceae.
\end{abstract}

Keywords : Heliantheae, ITS sequence, Podosphaera fusca, Reticuloidium

Zinnia (Zinnia elegans Jacq.) is a fast-growing annual plant native to Mexico that comprises many cultivars. The plants are widely cultivated in Korea in flower beds for ornamental purposes. In October 2008, about 1,000 zinnia planted around the ponds in Dumulmeori Park, Yangpyeong, Korea, were affected by a heavy infection of powdery mildew. Only a few leaves remained alive in the diseased plants. Microscopic examination of the leaves revealed that the powdery mildew was associated with an Oidium subgenus Reticuloidium, which is an anamorphic state of the genus

\footnotetext{
*Corresponding author.

Phone) +82-2-329-3063, FAX) +82-2-921-1715

E-mail)hdshin@korea.ac.kr
}

Golovinomyces. The finding of a Zinnia-Reticuloidium association was surprising, because zinnia occurring in Korea had previously been thought to be subject to mildew only by Podosphaera fusca (Fr.) U. Braun \& Shishkoff (Lee and Lee, 1967; Shin, 1994, 2000). Furthermore, such a widespread occurrence of powdery mildew infection of zinnia plants had never been observed (unpublished data).

Surveys of powdery mildew on zinnia. We conducted further surveys of zinnia powdery mildew from 2008-2010, and confirmed Golovinomyces infections in many localities of Korea. The voucher specimens collected during these surveys have been deposited in the herbarium of Korea University, Seoul. To our surprise, there was no evidence of powdery mildew infection due to $P$. fusca, which was previously thought to be main cause of powdery mildew infections in Korea. The surveys revealed two further zinnia widespread infections of Golovinomyces. Beginning on September 7, 2009, about 500 plants were heavily infected in a flower garden at Bukssang-ri, Nam-myeon, Yeongwol, Korea. A few days later, on September, 17, 2009, about 3,000 nearly-dead plants were discovered in ornamental zinnia flower gardens on the roadside at Dongmak-ri, Hwado-myeon, Ganghwa, Korea (Fig. 1A).

Morphological characteristics of powdery mildew fungus. Twenty four zinnia powdery mildew fungal samples were collected from many Korean localities during the 2008-2010 surveys. Morphological characteristics were ascertained by light microscopy examination using a model BX51 microscope (Olympus, Tokyo, Japan), based on a representative sample (KUS-F23894, Korea, Hongcheon, leg. M.J. Park \& H.D. Shin). Images were recorded using a Zeiss Axio imager microscope (Carl Zeiss, Göttingen, 


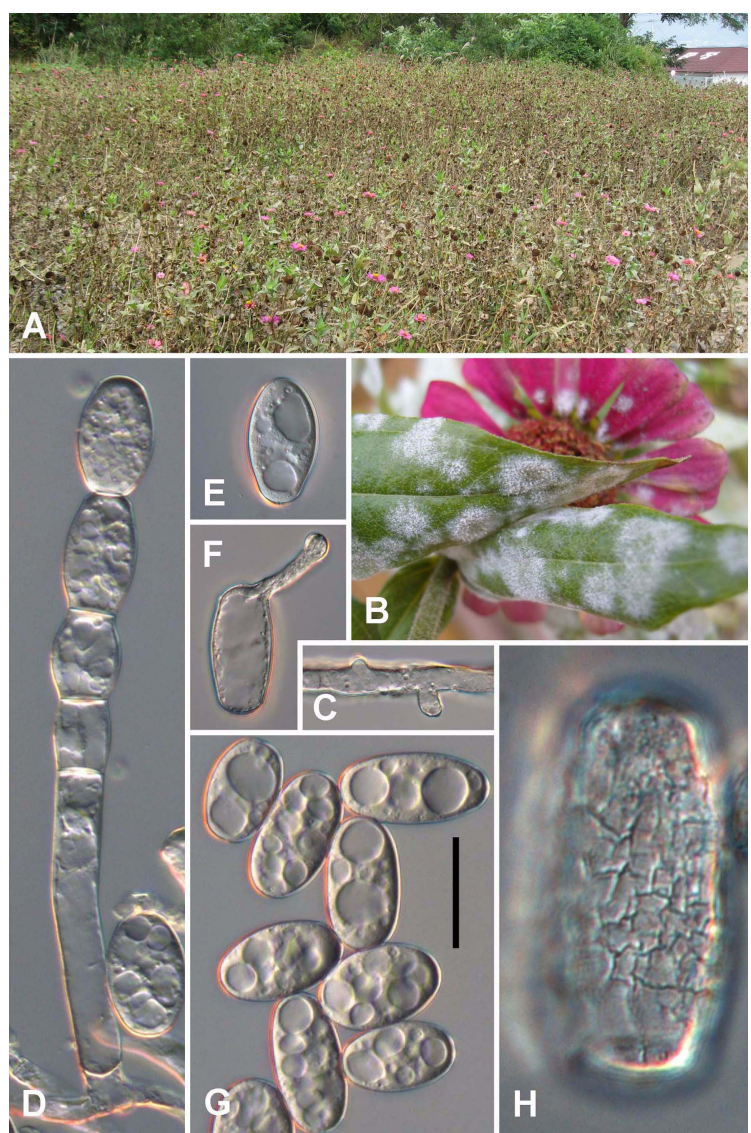

Fig. 1. Powdery mildew infections of Zinnia elegans by Golovinomyces cichoracearum. (A) Severe infections and early death of the plants were found in September 17, 2009, at a flower bed in Ganghwa, Korea. (B) Close-up view of infections on leaves and petals. (C) Hypha with nipple-shaped appressoria. (D) Conidiophore producing conidia in chains. (E) A first-formed conidium. (F) Germinating conidium. $(\mathrm{G})$ Conidia. $(\mathrm{H})$ Reticulate network of the conidium surface viewed with DIC microscopy. Bar $=30$ $\mu \mathrm{m}$ for $\mathrm{C}-\mathrm{G}$ and $10 \mu \mathrm{m}$ for $\mathrm{H}$.

Germany). Mycelia on both sides of leaves and also on stems and flower petals were subpersistent to subevanescent, forming circular to irregular white patches (Fig. 1B). Hyphae were sub-straight to wavy, occasionally geniculate, 40-80 $\mu \mathrm{m}$ long, 4-7 $\mu \mathrm{m}$ wide, mostly branching at a right angle, with a septum near the branching point. Hyphal appressoria were poorly developed, nipple-shaped, and single (Fig. 1C). Conidiophores were single on a hyphal cell, arising from the upper part of mother cells, $120-220 \times 10-13 \mu \mathrm{m}$, simple, straight in foot-cells, producing 2-6 immature conidia in chains with a sinuate edge, followed by 2-3 straight cells, with a basal septum at the branching point or slightly displaced from the mycelium (Fig. 1D). Conidia were ellipsoid to oval, $30-42 \times 16-22 \mu \mathrm{m}$ (length/breadth ratio $=1.4-$ 2.5), lacking distinct fibrosin bodies, producing germ tubes on the perihilar position, with reticulate wrinkling of the outer walls (Figs. 1F, 1G and 1H). First-formed conidia were apically conical, basally round to more or less subtruncate, and generally shorter (30-36 $\mu \mathrm{m}$ long) than the secondary conidia (Fig. 1E). No chasmothecia were found. The aforementioned structures were typical of the Oidium subgenus Reticuloidium anamorph of the genus Golovinomyces, and the measurements of the present fungus were compatible with those of G. cichoracearum (DC.) V. P. Heluta described previously (Braun, 1987; Nomura, 1997; Shin, 2000).

Additional specimens examined. Korea, Yangpyeong, 27 Oct 2008, M.J. Park \& H.D. Shin, KUS-F23914; Gangneung, 25 Oct 2008, B.S. Kim, KUS-F23934; Seoul, 6 Nov 2008, H.D. Shin, KUS-F23968; Suncheon, 2 Nov 2008, H.B. Lee, KUS-F23969; Suncheon, 1 Nov 2008, Y.J. Koh, KUS-F23970; Daejeon, 15 Nov 2008, H.G Kim, KUS-F23996; Daejeon, 16 Nov 2008, H.G. Kim, KUSF23997; Yeongwol, 7 Sep 2009, J.H. Park \& H.D. Shin, KUS-F24513; Ganghwa, 17 Sep 2009, M.J. Park \& H.D. Shin, KUS-F24615; Goesan, 20 Sep 2009, M.J. Park \& H.D. Shin, KUS-F24637; Chuncheon, 3 Oct 2009, H.D. Shin, KUS-F24699; Yangpyeong, 15 Oct 2009, J.H. Park \& H.D. Shin, KUS-F24753; Hongcheon, 18 Oct 2009, M.J. Park \& H.D. Shin, KUS-F24767; Seoul, 5 Aug 2010, H.D. Shin, KUS-F25131; Hoengseong, 12 Sep 2010, J.H. Park \& H.D. Shin, KUS-F25273; Seoul, 30 Sep 2010, H.D. Shin, KUS-F25380; Gwangju, 29 Sep 2010, H.B. Lee, KUSF25381; Cheongju, 5 Oct 2010, B.J. Cha, KUS-F25426; Gangneung, 5 Oct 2010, B.S. Kim, KUS-F25427; Suwon, 11 Sep 2010, S.G. Lee, KUS-F25475; Gongju, 10 Oct 2010, H.G. Kim, KUS-F25587; Geumsan, 11 Oct 2010, H.G Kim, KUS-F25588; Daejeon, 11 Oct 2010, H.G. Kim, KUSF25589.

Molecular analysis of powdery mildew fungus. To confirm the tentative identification based on morphological characteristics, molecular analysis of internal transcribed spacer (ITS) rDNA sequences from five representative materials (KUS-F23894, 23934, 23968, 23970, and 23997) was done. The complete ITS regions of rDNA were amplified with primers ITS5 and P3 as described by Takamatsu et al. (2009), and directly sequenced. All five ITS sequences were identical to each other and a resulting sequence of 508 bp from KUS-F23968 was deposited in GenBank (acc. no. HQ214032). A GenBank Blast search with the present data revealed an exact match for several sequences of $G$. cichoracearum including Australian powdery mildew on Zinnia sp., with a $100 \%$ sequence similarity. A phylogenetic tree was constructed with a representative sequence generated in this study and 24 sequences of $G$. cichoracearum retrieved from GenBank, using the neighbor-joining method 


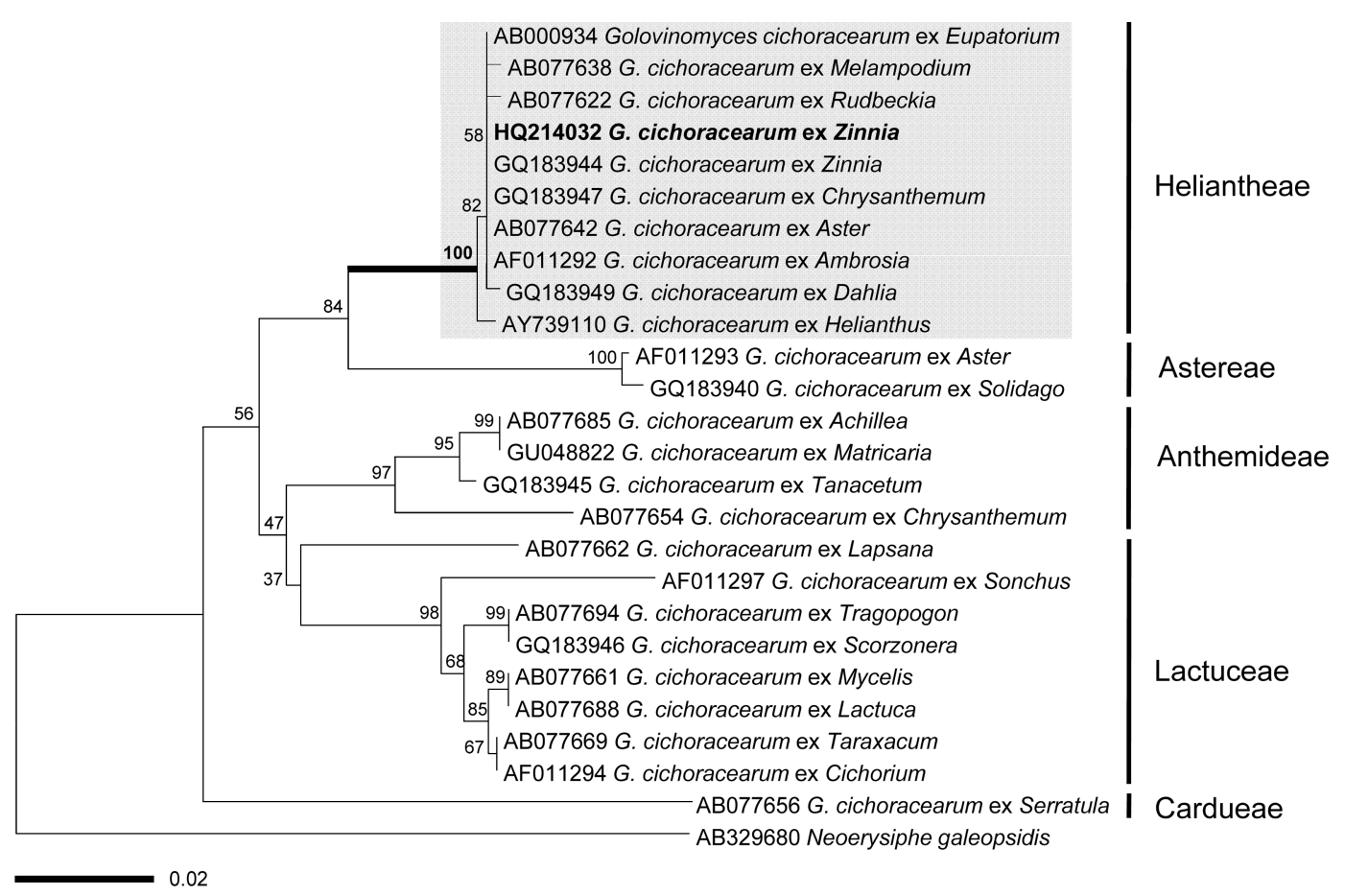

Fig. 2. Neighbor-joining tree showing phylogenetic relationship among Golovinomyces cichoracearum isolates inferred from the ITS rDNA regions. Bootstrap values based on 1000 replications are indicated above the branches and the scale bar represents 0.02 nucleotide substitutions per site.

in MEGA4 (Tamura et al., 2007). In a neighbor-joining tree (Fig. 2), the G. cichoracearum isolates were divided into five lineages according to the tribe of host plants, as demonstrated by Matsuda and Takamatsu (2003) and Cunnington et al. (2010). Korean powdery mildew on $Z$. elegans (Asteraceae, Heliantheae) was clustered into a clade that mainly contained G. cichoracearum isolates infecting hosts belonging to the Heliantheae (bootstrap value, 100\%).

Identification of powdery mildew fungus. Based on these morphological and molecular data, the fungus was identified as G. cichoracearum DC. During our extensive 3-year surveys of zinnia powdery mildew in Korea, all of 24 materials collected were identified as G. cichoracearum. Although we could not conclude that $P$. fusca infections of zinnia had disappeared in Korea, such infections could be very few in number.

Powdery mildew infections of $Z$. elegans associated with G. cichoracearum are nearly circumglobal, including Europe, North America, South America, Africa, Oceania, and Western Asian localities like India, Nepal, Jordan, and Israel (Braun, 1987; Bolay, 2005; Farr and Rossman, 2010; Voytyuk et al., 2009). On the other hand, P. fusca causes powdery mildew infections on zinnia in East Asia regions such as Japan (Nomura, 1997), China (Zheng and Yu, 1987), Taiwan (Hsieh, 1983), and Korea (Lee and Lee, 1967; Shin 1994, 2000).
Very interestingly, Hoshi et al. (2007) reported the occurrence of zinnia powdery mildew by Oidium subgenus Reticuloidium in Tokyo, Japan. Since the subgenus Reticuloidium is a sole anamorphic group of powdery mildew corresponding to the teleomorphic genus Golovinomyces (Cook et al., 1997; Glawe, 2008), the finding of zinnia powdery mildew in Japan in 2007 is, to our knowledge, the first report of Zinnia-Golovinomyces association in the Far East.

The present work confirms the occurrence or invasion of G. cichoracearum infecting Z. elegans in the Far East by an extensive, 3-year-long survey in Korea and by detailed morphological and molecular evidence.

\section{References}

Bolay, A. 2005. Les Oïdiums de Suisse (Erysiphacées). Cryptog. Helv. 20:1-176.

Braun, U. 1987. A Monograph of the Erysiphales (Powdery Mildews). Beih. Nova Hedw. 89:1-700.

Cook, R. T. A., Inman, A. J. and Billings, C. 1997. Identification and classification of powdery mildew anamorphs using light and scanning electron microscopy and host range data. Mycol. Res. 101:9751002.

Cunnington, J. H., Lawrie, A. C. and Pascoe, I. G 2010. Genetic characterization of the Golovinomyces cichoracearum complex in Australia. Plant Pathol. 59:158-164. 
Farr, D. F. and Rossman, A. Y. 2010. Fungal Databases, Systematic Mycology and Microbiology Laboratory, ARS, USDA. Retrieved October 25, 2010, from http://nt.ars-grin.gov/fungaldatabases/

Glawe, D. A. 2008. The powdery mildews: A review of the world's most familiar (yet poorly known) plant pathogens. Annu. Rev. Phytopathol. 46:27-51.

Hoshi, H., Sato, Y. and Horie, H. 2007. Occurrence of zinnia and Jerusalem artichoke powdery mildew by Oidium subgenus Reticuloidium, and host range of the subgenus of powdery mildew on several plants species occurred at Tokyo. Ann. Phytopathol. Soc. Japan 73(3):182 (abstract).

Hsieh, H. J. 1983. Notes on host plants of powdery mildew fungi found in Taiwan. (1) Host plants of Sphaerotheca fuliginea. Plant Prot. Bull. (Taiwan) 25:109-113.

Lee, H. J. and Lee, B. H. 1967. Unrecorded causal organisms of Korean powdery mildews (1). Korean J. Microbiol. 5:24-33. (in Korean)

Matsuda, S. and Takamatsu, S. 2003. Evolution of host-parasite relationships of Golovinomyces (Ascomycete: Erysiphaceae) inferred from nuclear rDNA sequences. Mol. Phylog. Evol.
27:314-327.

Nomura, Y. 1997. Taxonomical Study of Erysiphaceae of Japan. Yokendo Ltd., Tokyo, Japan. 281 pp.

Shin, H. D. 1994. Powdery mildew fungi and their host plants from Kangwon province. Korean J. Mycol. 22:229-246.

Shin, H. D. 2000. Erysiphaceae of Korea. Nat. Inst. Agric. Sci. Tech., Suwon, Korea. 320 pp.

Takamatsu, S., Heluta, V., Havrylenko, M. and Divarangkoon, R. 2009. Four powdery mildew species with catenate conidia infect Galium: molecular and morphological evidence. Mycol. Res. 113:117-129.

Tamura, K., Dudley, J., Nei, M. and Kumar, S. 2007. MEGA4: Molecular Evolutionary Genetics Analysis (MEGA) software version 4.0. Mol. Biol. Evol. 24:1596-1599.

Voytyuk, S. O., Heluta, V. P., Wasser, S. P., Nevo, E. and Takamatsu, S. 2009. Biodiversity of the Powdery Mildew Fungi (Erysiphales, Ascomycota) of Israel. A.R.G Gantner Verlag K.G. 290 pp.

Zheng, R. Y. and Yu, Y. N. (eds). 1987. Flora Fungorum Sinicorum. Vol. 1, Erysiphales. Science Press, Beijing, China. 552 pp. 